\title{
Copper Ores in Mawat Ophiolite Complex (Part of ZSZ) NE Iraq
}

\author{
Ali T. Yassin'1, Abdulkadhim J. Alabidi'2, Mohemmed L. Hussain ${ }^{3}$, Nadhir Al-Ansari4, \\ Sven Knutsson 4 \\ ${ }^{1}$ Iraq Geological Survey, Baghdad, Iraq \\ ${ }^{2}$ Geology Department, Faculty of Sciences, University of Kufa, Kufa, Iraq \\ ${ }^{3}$ Babylon University, Hila, Iraq \\ ${ }^{4}$ Nadhir Al-Ansari and Sven Knutsson, Lulea University of Technology, Lulea, Sweden \\ Email: alitahayassin@yahoo.com, Abdulkhadhim.alabidy@uokufa.edu, mlh960960@gmail.com, nad- \\ hir.alansari@ltu.se, Sven.knutsson@ltu.se
}

Received 15 September 2015; accepted 23 October 2015; published 29 October 2015

Copyright (C) 2015 by authors and Scientific Research Publishing Inc.

This work is licensed under the Creative Commons Attribution International License (CC BY).

http://creativecommons.org/licenses/by/4.0/

(c) (i) Open Access

\section{Abstract}

Ore microscopy study for some samples from Mawat complex NE Iraq (part of Zagros Suture Zone) showed the presence of copper ore minerals was irregularly distributed, mainly throughout the basic rocks of Mawat Ophiolite Complex. The main sulfides minerals identified were: chalcopyrite, pyrite, bornite, chalcocite and covellite. Iron hydroxides/oxides including goethite and magnetite were also observed associated with sulfide ore. Chalcopyrite and pyrite were the main primary minerals from which other ores were formed. They were originated at the orthomagmatic stage, and also deposited from aqueous solution of final stage in the consolidation of a magma forming vein textures which was observed in many samples. Two types of pyrite generations were recognized. They were pre-tectonic pyrite and post-tectonic pyrite. The secondary recognized ore textures were rim, pseudo morph, zoning, relicts, atoll and vein replacement textures. Secondary textures resulting from exsolution were also presented. Three stages of mineralization could be concluded: orthomagmatic stage (Earliest), the hydrothermal activations stage (Hypogene) and the weathering stage (Supergene). Paragenaticaly, the primary copper sulfides including chalcopyrite and bornite were responsible for other copper ores formation. These minerals were observed disseminated throughout the host mafic rocks which were considered as endogenic deposits (magmatic and hypogene origin) and they were modified as small patches of chalcocite and covellite.

\section{Keywords}

Iraq, Mawat, Ore, Ophiolite 


\section{Introduction}

Mawat area is located in Northeast Iraq (Figure 1). It consists of Mawatophiolite complex and Gimo sequence (metasedimentary rocks). The main goal of this paper is to identify the types of copper ores and other opaque minerals that exist with these minerals by reflected light microcopy and to clarify the relationship among the different minerals, their structures, textures and other characteristics as well as to clarify the origin of copper mineralization in this important area as a part of plate convergence boundaries; since more than half of the world's supply of copper is mined from deposits associated with plate convergence [1].

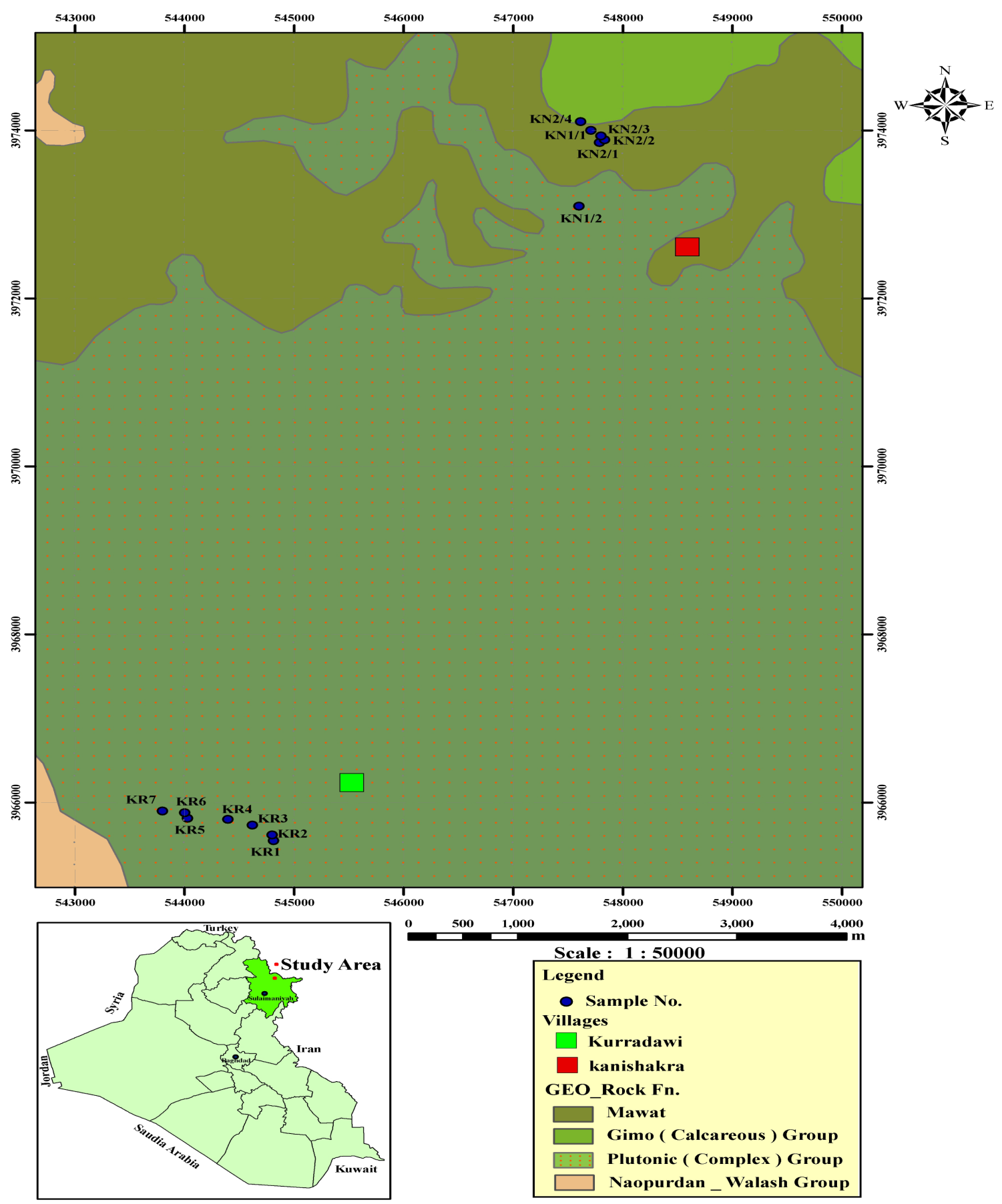

Figure 1. Location map shows study area and samples locations. 
Reflected light microscopy provides another window for petrology. It allows mineral identification of opaque minerals and considers as a method to interpret mineral paragenetic sequence in mineralized rocks. The studies on the microscopic intergrowth of metallic ores are the most commonly adopted method for obtaining one of the clues for divulging the order of growth of the minerals and elucidating the genesis and formation of the mineral deposits. Therefore, this paper will add another view for Mawat Ophiolite Complex based on ore microscopy work for some carefully picked samples from rich-copper deposits in this complex which is located in Kurradawi and Kanishakra areas about $32 \mathrm{~km}$ northeast of Sulaimaniya city (Figure 1).

\section{Geological and Tectonic Setting of Study Area}

\subsection{Geological Setting}

Al-Mehaidi [2] produced a geological map of the area with detail description of all rock units (Figure 1). He also indicated that the Mawatnappe consisted of Mawatophiolite complex and Gimo sequence (metasedimentary rocks). From the base to the top, the typical rock types of Mawatophiolite complex include ultramafic-mafic intrusions, sub volcanic, volcanic igneous rocks, and overlaid by oceanic sediments called (Gimo group). Gabbroic rocks lies in the central part of the ophiolite, about 1000 meters in thickness. They occupy about $170 \mathrm{~km}^{2}$ (70\%) associated with intermediate and acidic minor intrusions. They consist of medium to coarse grained and partly banded amphibolized gabbro, pyroxene gabbro, metagabbro, greenschist, epidosite and albite amphibolite. The ultramafic rocks are mainly peridotite (dunite, harzburgite and Iherzolite), pyroxenite and chromitite. This member's thickness reaches few meters to about 1500 meters in SerShiw area. They occupy about $15 \mathrm{~km}^{2}$.

\subsection{Tectonic Setting}

The study area is located in Penjwin-Walash Subzone within the Zagros Suture Zone (ZSZ) [3]. Mawatophiolite complex is a part of the Zagros-Thrust Belt, which extends of about 2000 kilometers from southeastern Turkey through northern Syria and Iraq to western and southern Iran [4]. It is represents one of the Tethyanophiolites, and it is considered to be part of the Le Crossant Ophiolitiqueperi-Arabe [5]. Zagros orogen is interpreted as the product of three major sequential geotectonic events: 1) subduction of New-Tethyan oceanic plate beneath the Iranian lithospheric plate during Early to Late Cretaceous; 2) emplacement (obduction) of a number of NewTethyan oceanic slivers (ophiolites) over the Arabian continental margin in Late Cretaceous (Turonian-Campanian) time; and 3) collision of the Arabian continental lithosphere with the Iranian plate in Miocene [6].

\section{Field Work and Sampling}

The mineralization outcrops were traced around Kurradawi and Kanishakra villages that were located on the basic body of Mawatophiolite complex. Fifteen samples were carefully picked from the copper mineralizations (Figure 1). All locations of these samples were confirmed by GPS type Garmen 12. The field work showed that the surrounding area of Kurradawi village had very important surface mineralzation zone extended about $800 \mathrm{~m}$ long and 1-2.5 m thick in the matagabbro host rocks. Field work also showed two promising mineralization zones within metabaslt at Kanishakra area. It is important to note that there are many difficulties accompanied the field works such as unexposed mines spread in the study area and the nature of mineralization which appeared disseminated and scattered.

\section{Methodology}

This work was based on ore microscopy technique supported by Scanning Electron Microscopy and Energy Dispersed Spectroscopy tool. Fifteen polished sections were prepared and examined under reflected light microscopy according to procedures described by [7]. The preparation of polished surface free from scratches, thermal and mechanical modification of the sample surface is essential for the examination, identification, and textural interpretation of ore minerals under reflected light, necessity grinding and polishing of specimens. The first stage was grinding to remove surface irregularities, reduce thickness, prepare a smooth surface for further work, and remove any zone of major deformation resulting from initial sample cutting.

Each sample was subjected for one hour to 200, 400, 600, 800 mesh abrasive respectively. The second stage was polishing of these specimens with diamond abrasives paste spread over a nap less cloth. The past permits 
the diamond grains to smoothen the surface without rolling and causing irregular scratching or gouging. $25 \mu \mathrm{m}$, $15 \mu \mathrm{m}$ diamond abrasives have been used respectively. Some samples subjected to final polishing less than $6 \mu \mathrm{m}$, $3 \mu \mathrm{m}$ and $1 \mu \mathrm{m}$, and to etching by $\mathrm{HNO}_{3}$ and $\mathrm{HCL}$, to clarify the ore textures. The polished sections were studied carefully under reflected light microscopy. Some samples were treated by $\mathrm{HCL}$ and $\mathrm{HNO}_{3}$ for etching where opaque minerals were commonly identified by applying a drop of reagent to the surface of the mineral grain to note whether the grain has been etched or otherwise affected or not.

Two polished sections have been appropriately chosen from and investigated under Scanning Electron Microscopy (SEM\&EDS) type TESCAN VEGA3 at Western Australia University; they were prepared by coating them with gold-coating of $200 \mathrm{~A}^{\circ}$ thickness for SEM observations and EDS analyses.

\section{Ore Mineralogy}

Chalcopyrite is the sulphide compound of iron and copper (Figure 2) and forms the major constituent ores observed as fine, medium and coarse grained subhedral-anhedral aggregates in disseminated pattern.

It was observed in metabasalt host rocks of Kanishakra area as disseminated form. This mineral is also observed filled veinlet (Figure 3(a)) revealing that chalcopyrite could be of hypogenic origin; where there is possibility that this mineral was precipitated directly from ascending magmatic solutions which derived their metal from magmas that crystallized later. It is commonly accompanied by such other sulphides like pyrite, chalcocite, covellite and bornite (Figure 3(b)) indicating to the alteration to supergene minerals by meteoric waters which has largely destroyed most of the primary chalcopyrite.
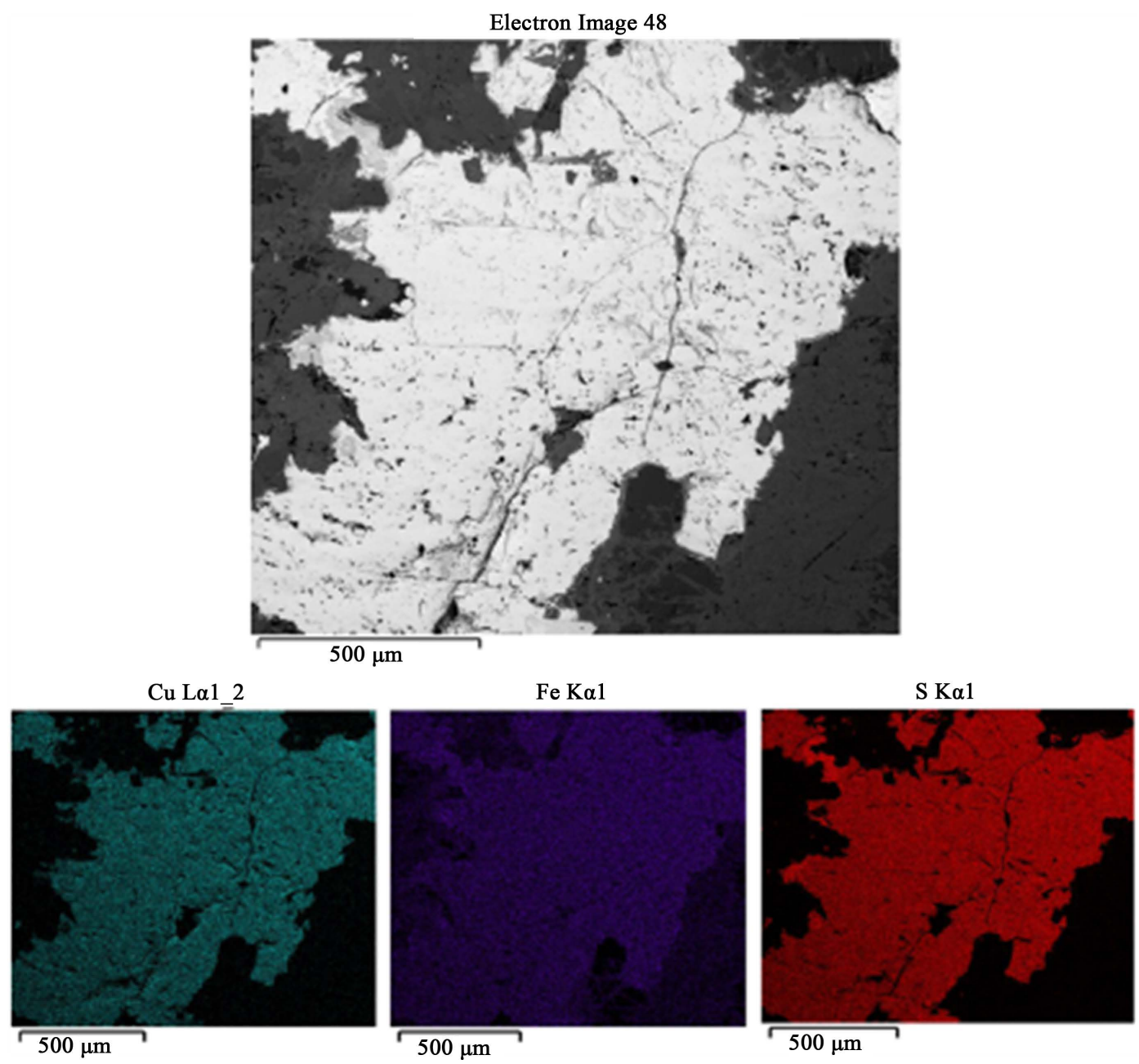

Figure 2. Backscattered image and elemental mapping shows chalcopyrite mineral. 


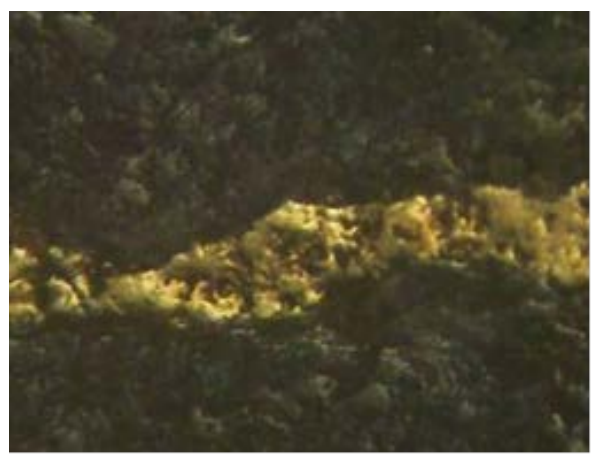

(a)

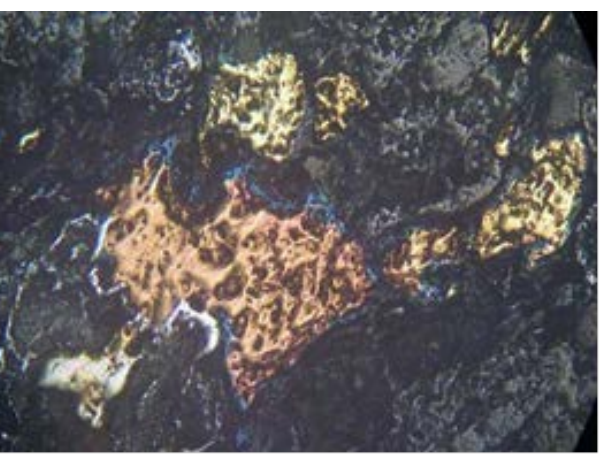

(b)

Figure 3. (a) Vein texture of chalcopyrite (yellow), after etching by $\mathrm{HNO}_{3}$, reflected light, 10×; (b) the association of sulphide minerals, bornite (brown) replaces chalcopyrite (yellow) and pyrite (white) surrounded by covellite (indigo blue), reflected light, 10×.

Covellite makes one of the most easily recognized of all minerals. It is widespread in most samples and clearly identified by its indigo blue color (Figure 4) and the absence of internal reflection (Craig and Vaughan, 1981). In addition to its reflection behavior which was blue in various shades, it shows negative reaction with both HCL and HNO3 [8].

Covellite has been noticed replacing the other sulphides minerals including chalcopyrite, pyrite and bornite composing many types of replacement textures. It sometimes forms euhedral crystals (Figure 5(a)). Covellite apparently formed during the second cycle enrichment in copper deposits by the oxidation and successive leaching of copper from more copper rich phases such as chalcopyrite, bornite and chalcocite [9].

Chalcocite is distinguished by its bluish white color under PPL and moderate reflectivity (Figure 5(b)), besides the negative reaction with $\mathrm{HCL}$ and strong effervescence by $\mathrm{HNO}_{3}$ [8]. It is found associated with other copper sulphide minerals as an alteration product [7].

Bornite has been recognized by its pinkish brown to orange and violet color under PPL with the absence of internal reflection besides its lower reflectivity in comparison with the other sulphides [7]. It is found replacing the chalcopyrite and pyrite as exosolution flames in the grains of these minerals (Figure 6(a)) altered to covellite mineral producing rim texture where it is surrounded by covellite was also observed (Figure 6(b)). This alteration indicated by the patches and relict of bornite within groundmass of covellite (Figure 6(c)).

Azurite and Malachite are resent as secondary minerals and they are closely related (Figure 6(d)) and clearly observed on the surface of mineralization areas. They were formed by weathering and oxidation of other $\mathrm{Cu}$-sulfides minerals. They are commonly found in oxidized zones of copper veins and deposits.

Pyrite is based on the petrographical observations; pyrite is the most common sulphide mineral in the studied area. Pyritization in this region are rather extensive and mostly is concentrated in a disseminated form in the rocks accompanied with chalcopyrite and sometimes in veinlets due to hydrothermal fluids originated from intrusive bodies and metamorphism which have gone through the cracks and fracture zone. Two types of pyrite generations were recognized in the studied samples. They are: Pre-tectonic pyrite and Post-tectonic pyrite. The pre-tectonic pyrite characterized by its deformation and highly fractured; this pyrite was probably deformed during regional tectonic events of Mawatophiolitcobduction. In the other side, the post-tectonic pyrite formed after these deformation events and characterized by undeformedeuhedral pyrite crystals (Figure 7(a)). The euhedral pyrite crystals are not affected by tectonic activation due to that they are formed, parageneticaly later [10].

Both these types of pyrite underwent highly alterations and they were replaced by secondary minerals; where the replacements goethite clearly observed around the margins of pyrite (Figure 7(b)) producing psuedomorph texture of goethite after pyrite as well as the relicts and rim textures which are good indicators of weathering.

Magnetite is the main iron oxides observed associated with sulphides, it was almost primary and identified by its negative reaction with $\mathrm{HNO}_{3}$, its color under PPL appeared as brownish gray to deep brown and confirmed by SEM and EDS analyses (Figure 8).

Goethite is mainly replacing the sulphide minerals especially pyrite and chalcopyrite (Figure 9), it is a secondary mineral composed by the oxidation of suphides under surface weathering circumstances. In comparison 


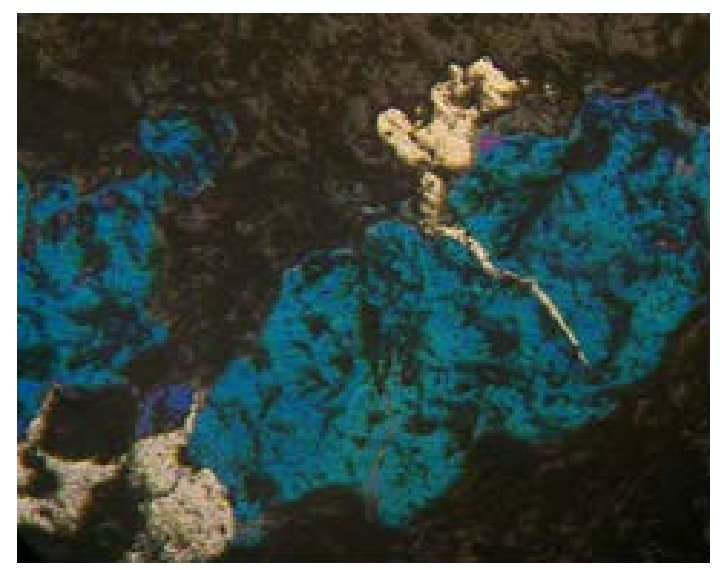

Figure 4: Covellite (indigo blue) replacing pyrite (white), reflected light, PPL, 10×.

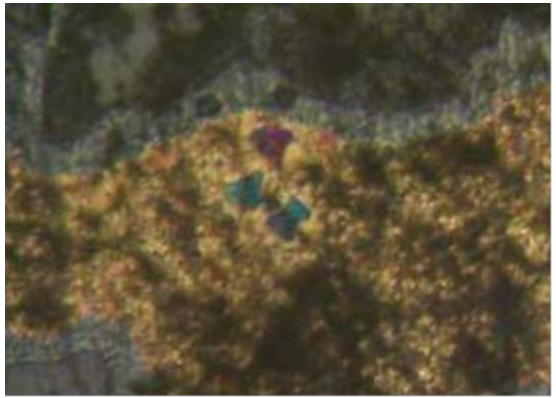

(a)

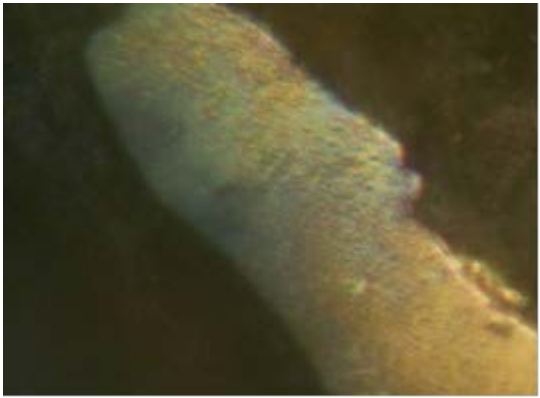

(b)

Figure 5. (a) Covellite (blue) replaces chalcopyrite (yellow) forming euhedral crystals shape all rimed by goethite (gray), reflected light, 10×; (b) Chalcocite (bluish white) replaces chalcopyrite (yellow), reflected light, PPL, 20×.
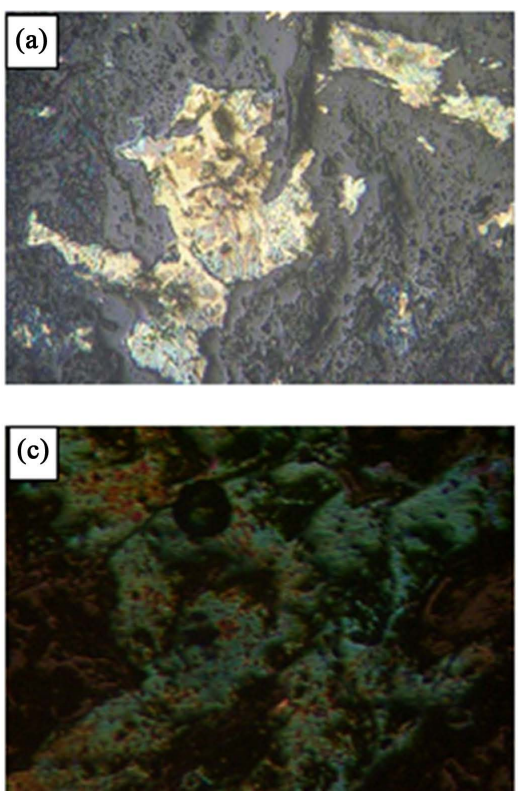
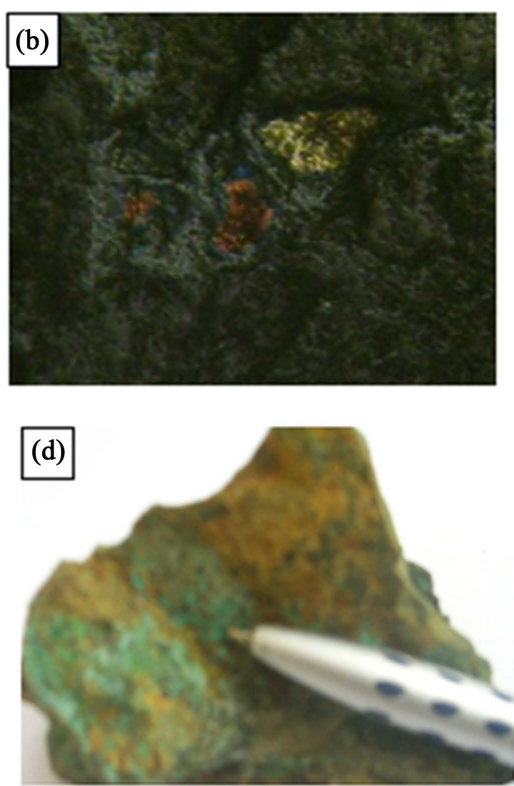

Figure 6. (a) Intergrown of chalcopyrite (yellow), bornite (brown), chalcocite (whitish blue) and covellite (blue), reflected light, 10×; (b) Rim texture covellite (blue) surrounds bornite (brown), reflected light, PPL, 10×; (c) Covellite (blue) replaces bornite (brown), reflected light, 10×; (d) Megascopic photo shows azurite (blue) and malachite (green). 

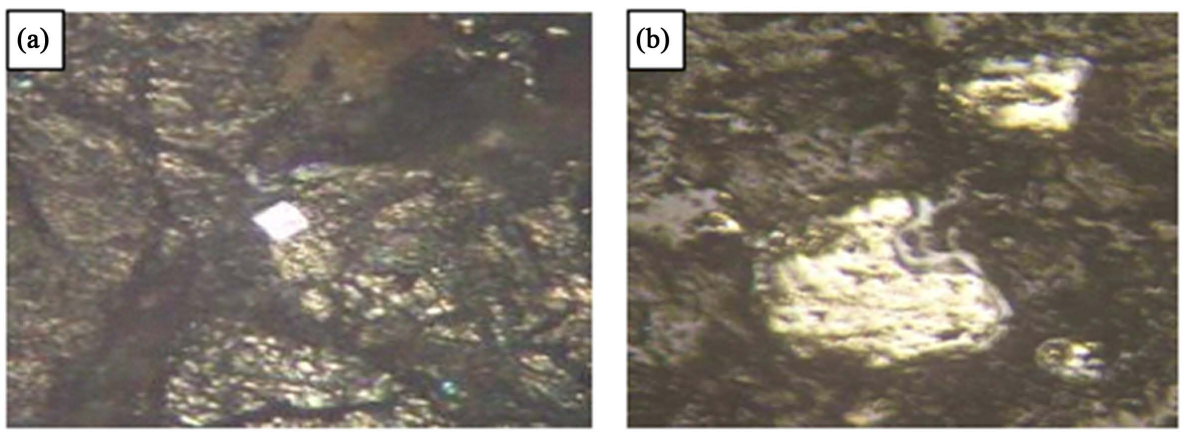

Figure 7. (a) Undeformed pyrite (off white), after etching by $\mathrm{HNO}_{3}, 20 \times$; (b) Rim texture of goethite (gray) surrounds pyrite (yellowish white), reflected light, PPL, 10×.
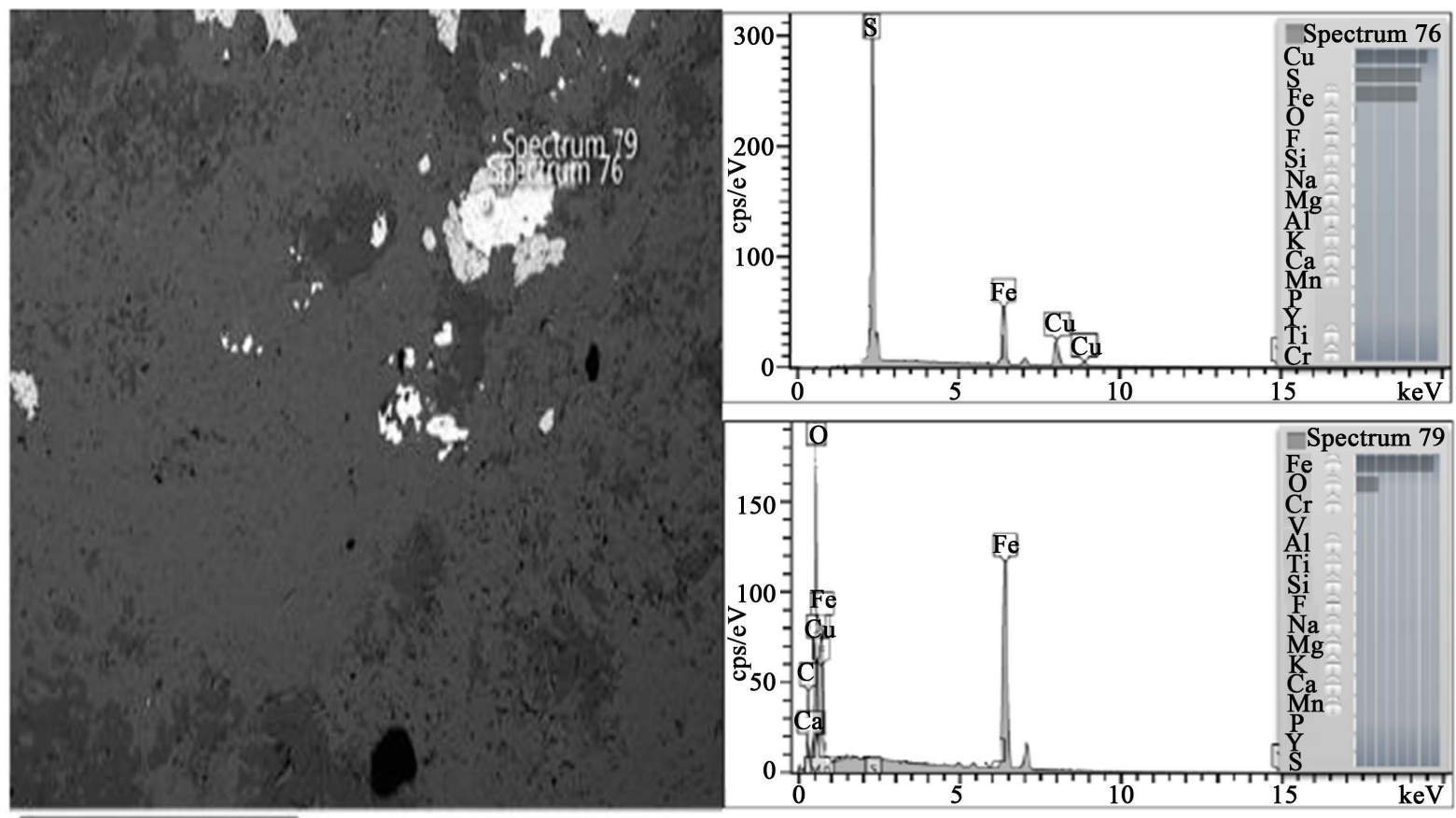

$1 \mathrm{~mm}$

Figure 8. Backscattered image and point chemical analyses show the association of magnetite and chalcopyrite.

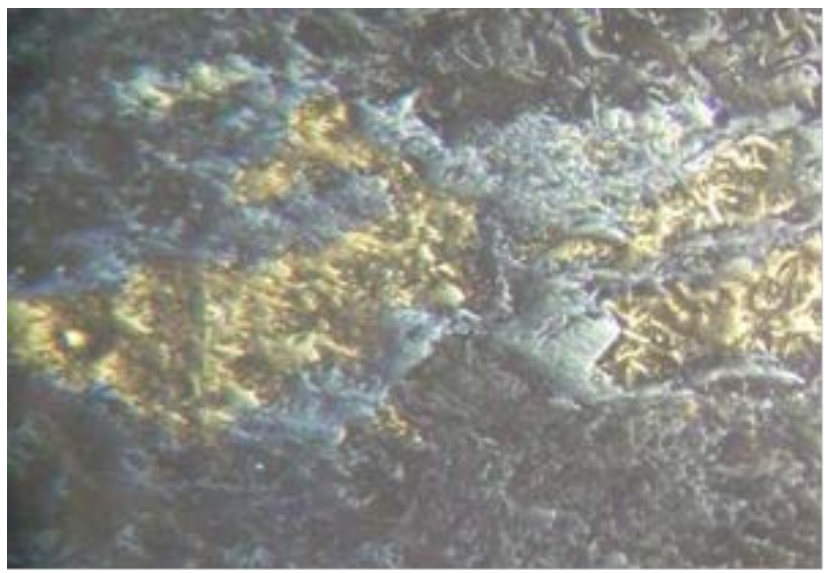

Figure 9. Goethite (grey) surrounds and penetrates chalcopyrite (yellow) due to oxidation process, reflected light, PPL, 10×. 
with other minerals it is very simple to identify by its gray color under plane polarized light with low reflectance and its distinct internal reflection which appeared as brownish yellow to reddish brown in color [7].

\section{Ore Textures}

Ore microscopy studies involved not only the identification of individual ore minerals, but also identifying the textures. These textures may provide evidence about the nature of such processes as initial ore deposition, post depositional re equilibration or metamorphism, deformation and weathering. The recognition and interpretation of textures is thus an important step in understanding the origin and post-depositional history of an ore [7]. In this work, primary textures of disseminated and open space filling texture, secondary textures resulting from replacement including weathering and exsolution textures have been recognized.

\subsection{Disseminated Texture (Primary)}

Most samples, especially those collected from Kanishakra area, were characterized by predominant of ore mineral, mainly subhedral and euhedral of chalcopyrite and pyrite crystals as disseminated pattern within the whole framework of the silicate minerals. This texture (Figure 10(a)) reveals that sulfide minerals concentrations were derived from immiscible sulfide liquids [8].
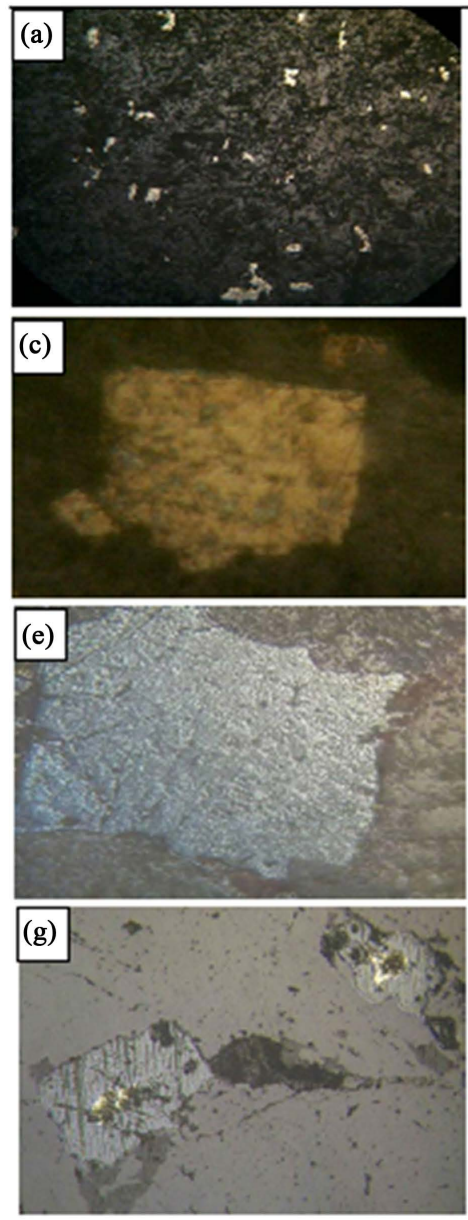
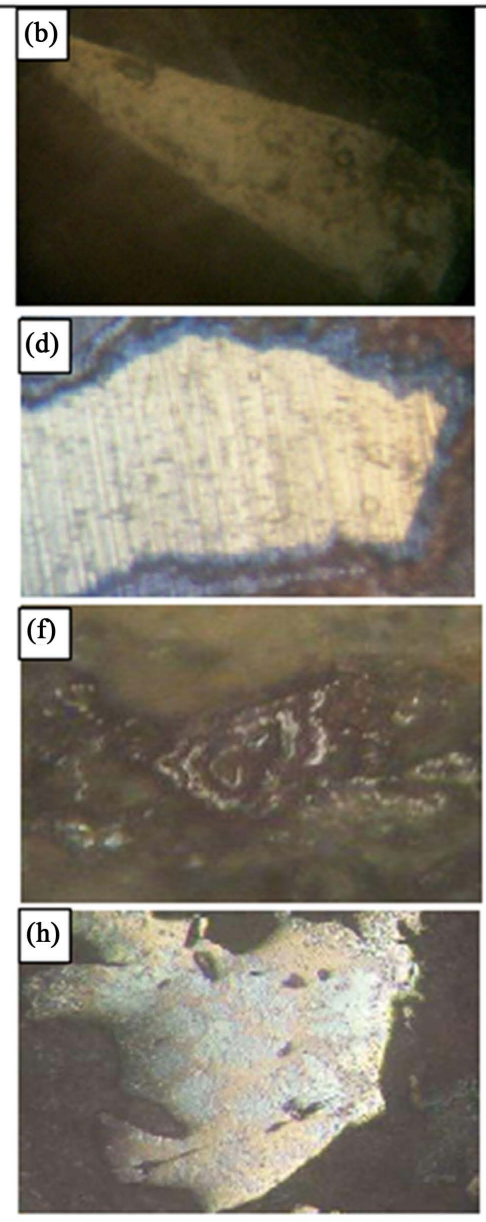

Figure 10. (a) Disseminated texture of sulphide ore minerals, reflected light, PPL, 5×; (b) Well-developed faces of chalcopyrite (yellow), reflected light, PPL, 20×; (c) Isolated cubes of pyrite, reflected light, PPL, 20×; (d) Rim texture of covellite (blue) surrounds chalcopyrite (yellow), reflected light, PPL, 20x; (e) Pseudomorph goethite (gray) after pyrite, reflected light, 10×; (f) Relict texture between goethite (gray) and chalcopyrite (yellow), reflected light, 10×; (g) Zoning texture after etching by $\mathrm{HNO}_{3}$, reflected light, 10×; (h) Atoll texture, after etching by $\mathrm{HNO}_{3}$, between chalcocite (bluish white) and chalcopyrite (yellow), reflected light, 20×. 


\subsection{Open-Space Filling Texture (Primary)}

The growth of ore minerals observed in vugs and open veins characterized by the formation of crystals with well-developed faces (Figure 10(b)). This texture developed on microscopic scale produced by the deposition from hydrothermal solutions in open fissures. Thus, pyrite isolated cubes (Figure 10(c)). This texture revealed the hypogene origin of related ore minerals [11].

\subsection{Secondary Textures Resulting from Replacement (Including Weathering).}

The replacement textures are widespread in all of the studied samples. Replacement of one ore mineral by another or by a mineral formed during weathering is common. This is as the result from one or more of the following processes: dissolution and subsequent reprecipitation, oxidation and solid state diffusion. The resulting boundary between the replaced and the replacing mineral is commonly either sharp and irregular (corroded texture) or diffuse [7]. There are many types of replacement textures that were recognized including: Rim, pseudomorph, zoning, relicts, a toll and vein replacement textures. These textures are composed of the mineral replacement due to fractures, cleavages and grain boundaries where the replacement is the result of a surface chemical reaction, hence any channel between grains or through grains is a prime site for initiation of the replacement processes [7]. Replacement especially supergene origin commonly develops a long grain boundaries composing a narrow rim around the host producing rim texture [11]. Rim texture is widely distributed in the studied samples and recognized between covellite and chalcopyrite, covellite and bornite; and sometimes with both. Goethite surrounds chalcopyrite and pyrite producing rim texture is also common (Figure 10(d)). Pseudomorph texture of iron oxides/hydroxides (especially goethite) after chalcopyrite and pyrite is clearly observed, this texture has been produced by the oxidation of iron which present in mineral phases bearing-iron under surface weathering circumstances (Figure 10(e)). Relict texture is widely distributed in most samples (Figure 10(f)). This texture gives explanation that the pseudomorphs of one mineral after another by replacement process with the preservation of original mineral. The formation of goethite after chalcopyrite and pyrite recognized and confirmed by the relicts of original sulfide embedded in the ground mass of goethite. This texture appears to result only from supergene replacement, under conditions which permit an intermittent supply of the oxidizing solutions [11]. Zoning texture was clearly recognized after etching (Figure 10(g)). The zonal replacement texture develop in oxidized ores, the zones marking successive stages in the rim replacement of isolated primary minerals grains [11]. The zonal texture (Figure 10(f)) developed from the progressive intermittent replacement of chalcopyrite by oxidizing solutions where the copper leached to form copper carbonates (malachite and azurite) while the iron was precipitated as limonite developing a concentric banding corresponding to the intermittent supply of oxidizing solutions [11]. Atoll texture is also observed which is known as core replacement texture [11] it is produced by replacement the internal core of the host mineral by invading, leaving the rim unreplaced. This texture observed between chalcopyrite and chalcocite where the crystals of chalcopyrite have been replaced in this way by chalcocite (Figure 10(h)). Vein replacement due to alteration is also observed between chalcopyrite and pyrite with covellite and goethite, (Figure 11).

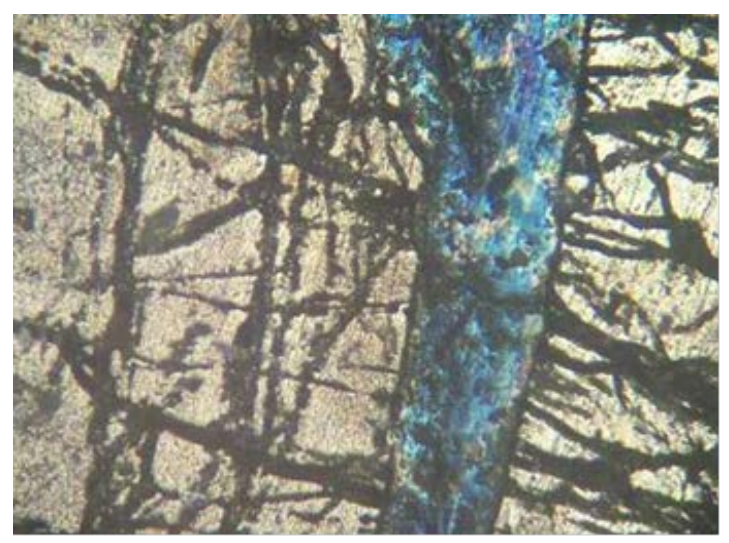

Figure 11. Vein replacement texture, chalcopyrite (yellow) and covellite (blue), after etching by $\mathrm{HNO}_{3}$, reflected light, 10×. 


\subsection{Secondary Textures Resulting from Deformation}

The brecciation texture of pyrite has been clearly observed (Figure 12). The cataclastic textures are widely common in most samples revealed the highly tectonic activations in the study area. The amount of brecciation depends on both the degree of deformation and the mineralogy of the ore [7], so pyrite showed high effect due to its brittle character and because it is harder than other ores.

\subsection{Secondary Texture Resulting from Exsolution}

Bornite has been observed embedded in chalcopyrite represents the exsolution texture (Figure 13) where the chalcopyrite is host phase and the exsolved phase [8]. In exsolution process, one phase is expelled from another under suitable conditions; the form of the exsolved phase varies with the involved minerals. The exsolution results from diffusion (usually of metal atoms through a sulfur or oxygen lattice), therefore it is clear that bornite expelled from chalcopyrite producing coherent exsolution texture because they are both in the tetragonal system [7].

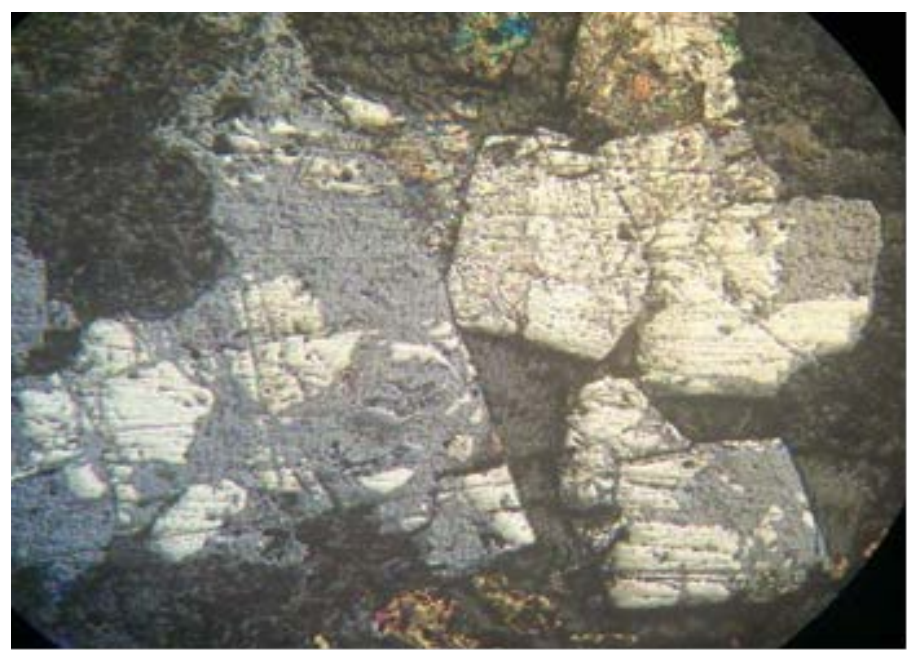

Figure 12. Cataclastic texture, Pyrite (yellowish white), chalcopyrite (yellow), covellite (blue), see the goethitziation of pyrite (grey), reflected light, 10×.

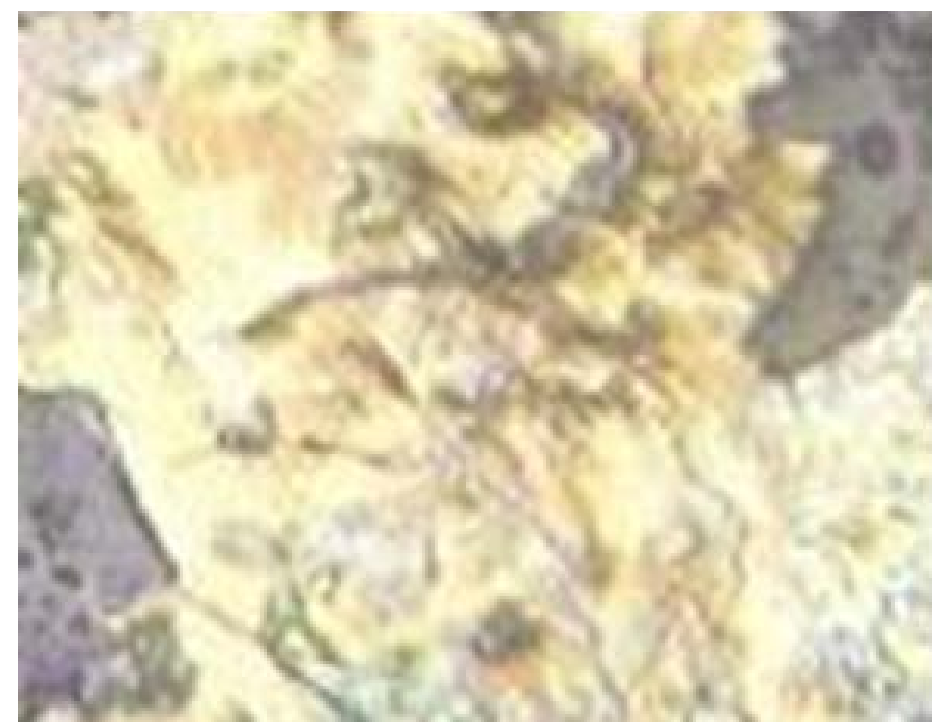

Figure 13. Exsolution texture, bornite (light brown) and chalcopyrite (yellow), after etching by $\mathrm{HNO}_{3}$, reflected light, $20 \times$. 


\section{Discussion of the Ore Minerals Paragenesis}

There is scant information about ore mineral textures in the copper rich deposits of Mawatophiolite complex. Therefore, this work may strengthen the view regarding ore textures. In Mawatophiolite, the primary copper sulfides including chalcopyrite and Bornite is responsible for the copper ore rich zones. These minerals are disseminated through the host mafic rocks representing the endogenic deposits (magmatic and hypogen origin). They are also modified by small patches of chalcocite and covellite. The later showed rims around the margins of chalcopyrite in many samples as mentioned before. The intergrowths such as these can be interpreted as a result of replacement processes represents supergene origin supported by goethitization of iron-sulfide minerals which is observed as pseudomorph and relict texture and also rim texture, as well [12].

Ore genesis and parageneses could be discussed hereinafter to conclude the mineralization epochs. Ore microscopy investigations for studied samples showed that there are many factors contributed in the formation of Mawat-copper rich deposits starting in orthomagmatic stage which formed the disseminated pattern of cu-rich sulphide ores a cross the hydrothermal activations that produced hypogene ore minerals filled veinlets and fissures ultimatum to supergene enrichment processes under surface weathering circumstances which caused high alterations of primary sulphide minerals forming the recent secondary ores. Part of Chalcopyrite and pyrite formed during orthomagmatic stage (these two minerals are the parents for other ore minerals formed at later stages), at this epoch, the immiscible sulfide liquids from mafic magmas are the fundamental process that formed the magmatic sulfide minerals. Once formed droplets \& immiscible sulfide liquid settle through less dense silicate magma, The sulfide liquid acts a (collector ) for copper and probably platinum group elements (PGE) because these elements are preferentially concentrated in sulfides liquids at levels 10 to 100.000 times those in silicates liquids. To a lesser extent, iron is also preferentially partitioned in too sulfide liquid (because of its greater abundance) and most immiscible sulfide liquid is iron-rich. This may give interpretation for why there is combined mineralization between iron and copper in Mawatophiolite complex [13]. Therefore, in this stage, the primary minerals including chalcopyrite and pyrite have been formed supported by the widely distribution of disseminated textures in studied samples especially in metagabro and metabasalt host rocks. This type of mineralization can also be classified as syngenetic ores depending on time relations to rock enclosing or associated with them.

Another mineralization epoch plays a significant role in forming the copper enrichment deposits at Mawatophiolite complex is Hydrothermal stage. Ore microscopy investigations showed that there is another type of primary chalcopyrite formation which has been deposited from aqueous solutions represents the final stage in the magma consolidation (Hypogene origin). These solutions have found their way along great distances from their parent source, eventually, by cooling or chemical reaction they are compelled to deposit their load in cavities and fissures composing vein texture. This type of mineralization can also be classified as epigenetic ores due to their formation was later than host rock formation.

The final stage of the mineralization is Supergene enrichment stage. Like other rocks, ore deposits undergo to weathering and decomposition at their outcrops. In the studied samples it is clearly that primary sulfide minerals underwent high alterations under surface weathering circumstances producing other ores and minerals. This mineralization is widespread throughout the whole study area.

Thus, the paragenesis depending upon the textural relationships of the ore minerals can be deciphered that the main minerals subjected to secondary enrichment are chalcopyrite and pyrite; these minerals crystallized first during two stages including crystallization from immiscible sulfides liquids and from hypogene solutions. Then, bornite replaced chalcopyrite as a result of exsolution processes due to activations of hypogene solutions. Chalcocite clearly showed supergene in origin and crystallized from both bornite and chalcopyrite. Covellite is a product of decomposition of other sulfides. It was clearly originated from chalcopyrite producing rim texture in addition to secondary pyrite which resulted by product. Iron oxides/hydroxides minerals formed later under agents of surface weathering circumstances, even though there is sometimes primary magnetite observed associated with chalcopyrite which seem to be formed at early stages of rock formation history where magnetite intergrowth with chalcopyrite are evidence of magnetite formation during the main event of hypogene mineralization. Azurite and malachite are obviously supergene in origin produced from other copper sulphide minerals at the last stage of mineralization. According to the ore microscopy investigations of the studied samples, the probable paragenesis can therefore be clarified in Table 1 . 
Table 1. Shows the proposed parageneses for ore minerals of the study area.

\begin{tabular}{cccc}
\hline Ore Minerals & Orthomagmatic Stage (Earliest) & Hydrothermal Stage (Hypogene) & Weathering Stage (Supergene) \\
\hline Chalcopyrite & - & \\
Pyrite & & \\
Bornite & & - \\
Chalcocite & \\
Covellite & \\
Azutire & \\
Malachite & \\
Magnetite & \\
Goethite & \\
\hline
\end{tabular}

\section{Conclusions}

The major conclusions reached from this work are:

1. Copper-rich deposits of Mawat Ophiolite Complex are characterized by the presence of copper sulphides minerals including Chalcopyrite, Bornite, Chalcocite and Covellite.

2. Clalcopyrite and bornite are almost primary in origin. The former is formed at orthomagmatic stage supported by disseminated texture, and also formed from aqueous solutions associated with bornite revealed the hypogene origin for both.

3. Chalcocite and covellite are supergene ore minerals produced by the alterations of aforementioned primary sulphide ores.

4. Pre-tectonic pyrite (deformed pyrite) and post-tectonic pyrite (undeformed pyrite, euhedral) give indications for many mineralization periods before and after tectonic events.

5. Primary and secondary ore textures are coexisting; the former is represented by disseminated texture (orthomagmatic origin) and open-space filling (hypogene origin). The later (supergene origin) includes replacement textures which are rim, pseudomorph, zoning, relicts, atoll and vein replacement textures.

6. The paragenetic sequence of the copper ore mineralization is probably as follow: Chalcopyrite, bornite, chalcocite, covellite, azurite, malachite.

7. Based upon our evaluation of examined samples, probably there is an economic concentration of copper that could be found under the surface of the studied area, because of the Oxidation of covellite that leads to the transportation of copper to the subsurface zone of second cycle enrichment.

\section{References}

[1] Plumer, C.C., Carlson, D.H. and Hammersley, L. (2013) Physical Geology. 14th Edition, McGraw Hill Inc., 635 p.

[2] Al-Mehaidi, H.M. (1974) Geological Investigation of Mawat-Chwarta Area NE of Iraq. GEOSURV, Iraq, Internal Report No. 609.

[3] Jassim, S.Z. and Goff, C. (2006) Geology of Iraq. Published by Dolin, Prague and Moravian Museum, Brno, 341 p.

[4] Alavi, M. (2004) Regional Stratigraphy of the Zagros Fold-Thrust Belt of Iran and Its Proforeland Evolution. American Journal of Science, 304, 1-20. http://dx.doi.org/10.2475/ajs.304.1.1

[5] Ricou, L.E. (1971) Le Croissant ophiolitique Peri-Arab: Uneceinture de nappesmises en place an Cretacesuperieur. Revue Geographique Physique et Geologie Dynamique, 13, 327-349.

[6] Mohammad, Y.O. (2008) Petrology of Ultramafic and Related Rocks along Iraqi Zagros Thrust Zone. PhD Thesis, Osaka Prefecture University, Sakai, 138 p.

[7] Craig, J.R. and Vaughan, D.J. (1981) Ore Microscopy and Ore Petrology. John Wiley \& Sons. Inc., Hoboken, 406 p.

[8] Ramdohr, P. (1981) The Ore Minerals and Their Intergrowth. Pergamon Press., New York, 1202 p.

[9] Walash, C.A. and Rimstiut, J.D. (1986) Retas of Reaction of Covellite and Blaplei Bender Covellite with Ferric Iron at PH 2.0. Canadian Mineralogist, 24, 35-44. 
[10] Abdollahi, M.J., Karimpar, M.H. and Kheradmand, A. (2009) Petrography and Sulphur Isotope Studies of Pyrites in the Mutch Gold Deposite. American Journal of Applied Sciences, 6, 1086-1092. http://dx.doi.org/10.3844/ajassp.2009.1086.1092

[11] Edwards, A.B. (1960) Textures of the Ore Minerals. The Australian Institute of Mining and Metallurgy, Victoria, 242 p.

[12] Lufkin, J.L. (2010) Origin of Ore Textures: Porphyry Copper Deposits, Rocky Mountain. 62th Annual Meeting of Geological Society of America (GSA), Vol. 42, No. 3, 1.

[13] Musa, E.O. (2007) Petrography, Geochemistry and Genesis of Copper-Iron Mineralization and Associated Rocks in Waraz Area, Sulaimanya, NE Iraq. Unpubl. M. Sc. Thesis, University of Baghdad, Baghdad, 155 p. 